\title{
Subacute Sclerosing Panencephalitis with Subclinical Infection
}

\author{
V. A. Kotrashetti ${ }^{1}$, Vijay Baburao Sonawane ${ }^{\circledR 2}$, Kapil Bainade ${ }^{\circledR 3}$, Shweta Nair ${ }^{\circledR 4}$, Amit Vatkar ${ }^{\circledR 3}$, Santosh Kumar ${ }^{\odot 5}$ \\ ${ }^{1}$ Professor, DY Patil Hospital, Vidyanagar, Sector 5, Nerul, Navi Mumbai, Maharashtra, India, ${ }^{2}$ Associate Professor, DY Patil Hospital, Vidyanagar, Sector 5, Navi Mumbai, \\ Maharashtra, India, ${ }^{3}$ Assistant Professor, DY Patil Hospital, Vidyanagar, Sector 5, Nerul, Navi Mumbai, Maharashtra, India, ${ }^{4}$ Senior Resident, DY Patil Hospital, \\ Vidyanagar, Sector 5, Nerul, Navi Mumbai, Maharashtra, India, 5 Junior Resident, DY Patil Hospital, Vidyanagar, Sector 5, Nerul, Navi Mumbai, Maharashtra, India.
}

\section{Abstract}

Subacute Sclerosing Panencephalitis (SSPE) is a chronic complication of measles. It is a neurodegenerative disorder characterized by cognitive and memory deterioration, behaviour abnormalities, involuntary movements and repetitive myoclonic jerks and a steady motor decline. We report a case of a 7-year-old girl with subacute sclerosing panencephalitis presenting with myoclonic jerks, regression of motor milestones and speech. The child was not immunised for measles. Magnetic resonance imaging revealed multiple variable-sized ill-defined T2W and FLAIR hyperintense areas are seen involving the white matter of the bilateral fronto-parietal lobes. Electroencephalograph findings and CSF analysis confirmed the diagnosis of subacute sclerosing panencephalitis.

Keywords: Subacute Sclerosing Panencephalitis, Neurodegenerative, Myoclonic Jerks

Corresponding Author: Shweta Nair, Senior Resident, DY Patil Hospital, Vidyanagar, Sector 5, Nerul, Navi Mumbai, Maharashtra, India. E-mail: shwnair@gmail.com

Received: 05 July 2020

Revised: 15 August 2020

Accepted: 21 August 2020

Published: 22 December 2020

\section{Introduction}

Subacute Sclerosing Panencephalitis (SSPE) is a neurodegenerative disorder due to a persistent infection with a mutated wild measles virus that is harboured intracellularly in the central nervous system for several years. ${ }^{[1,2]}$ After 7-10 years the virus regains virulence and attacks the cells in the central nervous system resulting in inflammation and cell death, leading to a neurodegenerative process. Measles at an early age favours the development of SSPE. Measles is still a common communicable disease, particularly in Africa and Asia. As per the recent WHO report, 7 million people were found to be affected with measles in 2016. ${ }^{[3-5]}$ Approximately, 38\% of Indian children fail to receive the basic immunization in the first year of life. ${ }^{[6]}$ Approximately $50 \%$ of the global measles-associated deaths occur in India. ${ }^{[7,8]}$ The pathogenesis of SSPE remains difficult to interpret, factors involved are defective measles virus and interaction with a defective or immature immune system. The virus isolated from brain tissue of patients with SSPE lacks the matrix or M protein one of the 6 structural proteins. Clinical manifestation begins insidiously 7-13 years after primary measles infection.

We discuss a 7-year old girl with SSPE presenting with myoclonic jerks, regression of motor milestones and speech. The diagnosis was confirmed by elevated anti-measles anti- bodies titres in CSF and periodic complexes on an electroencephalogram.

\section{Case Report}

A 7-year-old girl born of the non-consanguineous marriage, presented with myoclonic jerks since lyear and regression of motor milestones and speech since 1month. The patient developed jerky movements of head each occurring at an interval of 5-10 mins. This lasted for a year which gradually involved upper limbs and lower limbs for one month. There was a regression of motor-milestones and speech. Currently, she can stand with support and can speak 2-3 word phrases. These abnormal movements resulted in clumsiness, incoordination and difficulty in performing daily activities. There was no history of visual or hearing disturbance. She had not been immunised for measles. Birth history was normal. Development of the child was normal till 6 years of age.

On examination, she was conscious, oriented to person. She has slurred speech with small phrases comprising of 2-3 words. She has a periodic brief, sudden, myoclonic jerks resulting in imbalance and frequent falls. Sensory, motor system and cranial nerve examination were normal. Fundoscopy was normal. 
Electroencephalogram showed large-amplitude periodic complexes, these periodic complexes repeat at fairly regular 410 second intervals and have 1:1 relationship with myoclonic jerks [Figure 1], magnetic resonance imaging (MRI) showed multiple variable-sized ill-defined T2W and FLAIR hyperintense areas are seen involving the white matter of the bilateral fronto-parietal lobes [Figure 2], No restriction on diffusionweighted images or blooming on gradient images is noted. No enhancement is seen in the post-contrast study. Anti-measles antibodies titres were elevated in both blood and CSF [Table 1]. With these findings a diagnosis of SSPE is confirmed most likely Stage II. Tablet valproic acid and Tablet Clobazam was started to control myoclonic jerks. Occupational therapy was started to aid the child in feeding and Physiotherapy was started to prevent contractures as the child was bedridden, immunization advice was given and she was discharged on oral Valproic acid $(36 \mathrm{mg} / \mathrm{kg} /$ day) in two divided doses and Tablet Clobazam (10mg/day). Other drugs like Isoprinosine, interferons are not prescribed due to financial constraints.

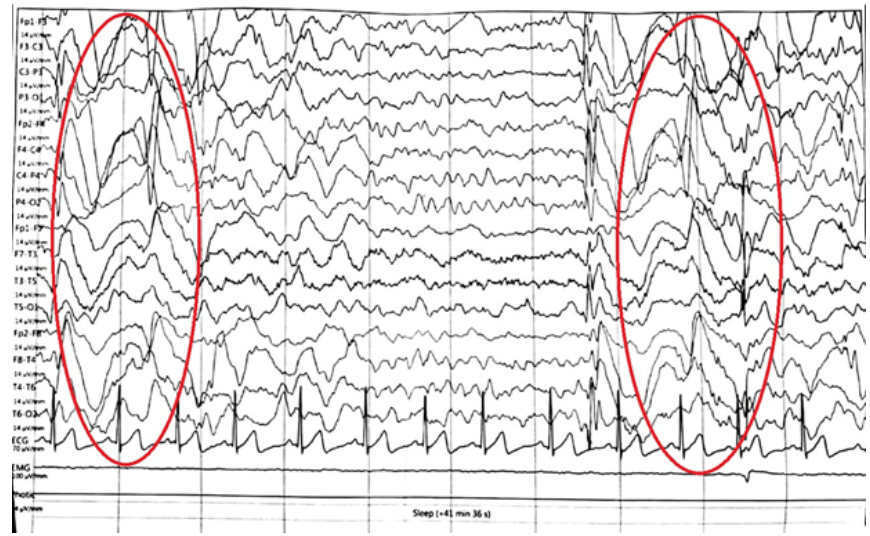

\section{Figure 1: EEG showing periodic complexes}

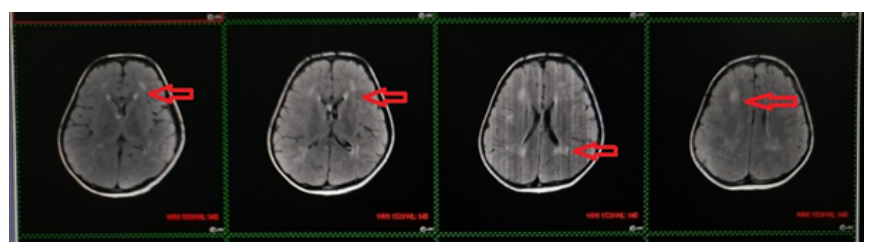

Figure 2: MRI showing hyper-intense areas involving white matter.

\section{Discussion}

We discuss a case of SSPE with myoclonic jerks and white matter hyperintensities of bilateral fronto-parietal lobes classifying it as a stage 2 disease. The clinical course of

\begin{tabular}{|c|c|c|c|}
\hline Investigation & $\begin{array}{l}\text { Observed } \\
\text { value }\end{array}$ & Unit & $\begin{array}{l}\text { Biological refer- } \\
\text { ence interval }\end{array}$ \\
\hline $\begin{array}{l}\text { Serum IgG } \\
\text { measles }\end{array}$ & 10250 & $\mathrm{U} / \mathrm{ml}$ & \\
\hline $\begin{array}{l}\text { CSF IgG } \\
\text { measles }\end{array}$ & 15000 & $\mathrm{U} / \mathrm{ml}$ & \\
\hline $\begin{array}{l}\text { Serum total } \\
\text { IgG }\end{array}$ & 2040 & $\mathrm{mg} / \mathrm{dl}$ & $700-1600$ \\
\hline $\begin{array}{l}\text { CSF total } \\
\text { IgG }\end{array}$ & 16.3 & $\mathrm{mg} / \mathrm{dl}$ & $0-3.4$ \\
\hline $\begin{array}{l}\text { CSF/serum } \\
\text { Quotient } \\
\text { reference }\end{array}$ & 5.8 & & $\begin{array}{lr}\text { Normal } & <1.3 \\
\text { Equivocal } & 1.3-1.5 \\
\text { Positive }>1.5\end{array}$ \\
\hline
\end{tabular}

the disease can be classified into 4 stages. The initial phase (stage 1) is characterised by irritability, reduced attention span, poor scholastic performance and temper tantrums. In the $2^{\text {nd }}$ stage, involuntary movements and repetitive myoclonic jerks appear but the consciousness is maintained. In the $3^{\text {rd }}$ stage, involuntary movements disappear and are replaced by choreoathetosis, immobility, dystonia and lead pipe rigidity due to involvement of basal ganglia. The sensorium deteriorates into dementia, stupor and then coma. In the $4^{\text {th }}$ stage, vital centres located in the brainstem get involved and soon death ensues. In acute fulminant SSPE the disease progression is rapidly leading to death within three months of the diagnosis. In the series of Risk and Haddad, approximately $10 \%$ of patients had such a fulminant course. ${ }^{[8-10]}$ In acute fulminant SSPE various stages of the disease cannot be recognised. Ocular and visual manifestations are reported in $10 \%-50 \%$ of patients, which include cortical blindness, chorioretinitis, and optic atrophy. ${ }^{[1]}$ Visual symptoms usually occur along with neurological manifestations but they may precede neurological manifestation by several years. ${ }^{[12,13]}$ Park et al, in a patient presenting with chorioretinitis, have demonstrated numerous filamentous, microtubular, and intranuclear viral inclusions in the nuclear layers of retina consistent with the measles virus. ${ }^{[14]}$

Subacute Sclerosing Panencephalitis is diagnosed on the basis of typical clinical features and at least one of the following supporting findings 1 . Presence of periodic complexes in electroencephalograph, 2.Elevated anti-measles IgG in CSF and serum, 3.Typical histologic features in brain biopsy specimen and/or isolation of virus or viral antigen from brain tissue. There is no definitive cure for SSPE although many drugs have been tried with conflicting results. Amantadine is an anti-RNA agent, very well absorbed from the gastrointestinal tract, and crosses the blood-brain barrier, but the response to treatment 
in few cases of SSPE is disappointing. ${ }^{[9]}$ In isolated reports, interferon beta plus Inosiplex intravenous immunoglobulin plasmapharesis, and corticosteroids have been tried with variable results. ${ }^{[10,11]}$ The average survival is $1-3$ years since the onset of symptoms. Incidence of SSPE has decreased in nations with good measles vaccination coverage.

SSPE can have an atypical presentation with generalised choreoathetosis and bilateral putamenal hyperintensities in stage 1 of the disease. Choreoathetosis if present usually manifests in advanced stages of the disease along with rigidity, motor and cognitive impairment. Radiographic findings are a normal MRI or subtle, multifocal subcortical changes in stage 1; periventricular and subcortical white matter involvement in stage 2; cortical, subcortical, periventricular, and corpus callosum involvement and brain atrophy in stage 3; cortical, subcortical, brain stem, and cerebellar involvement and brain atrophy in stage IV of SSPE.

Measles vaccination reduces the risk of measles infection and SSPE. ${ }^{[1]}$ Because infants infected with measles are at highest risk for SSPE, it is important to protect them by vaccination and herd immunity. ${ }^{[3]}$ Some cases have no known history of febrile rash illness, but the SSPE diagnosis indicates a subclinical or mild form of infection. ${ }^{[1]}$ SSPE diagnosis during pregnancy has been reported in the literature, suggesting that the altered immune system during pregnancy might permit the virus, if present, to replicate in the central nervous system ${ }^{4}$. SSPE is generally a simple diagnosis to make, requiring only CSF antibody testing that can be performed in public health and clinical laboratories. ${ }^{[3]}$

\section{Conclusion}

In conclusion, SSPE which is a chronic complication of measles infection is a devastating neurodegenerative condition, the clinical presentation of our case was with myoclonic jerks, regression of speech and motor milestones. The child was not immunised for measles, she had no evidence of prior measles infection. CSF revealed elevated anti-measles antibodies titres and EEG showed periodic complexes thus confirming the diagnosis of SSPE. Management of SSPE is primarily supportive. Isoprinosine clinical trials with or without interferon use suggest significant benefit. Clobazam and valproic acid are of significant benefit in the control of myoclonic jerks in the early stages of illness.

\section{References}

1. Upadhyayula P, Yang J, Yue J, Ciacci J. Subacute Sclerosing Panencephalitis of the Brainstem as a Clinical Entity. Med
Scien. 2017;5(4):26-26. Available from: https://dx.doi.org/10. 3390/medsci5040026.

2. Fisher DL, Defres S, Solomon T. Measles-induced encephalitis. Int J Med. 2015;108(3):177-182.

3. Huber M, Pawlik G, Bamborschke S, Finke GR, Karbe H, Schlenker M, et al. Changing patterns of glucose metabolism during the course of subacute sclerosing panencephalitis as measured with18FDG-positron-emission tomography. J Neurol. 1992;239(3):157-161. Available from: https://dx.doi. org/10.1007/bf00833917.

4. Chiu MH, Meatherall B, Nikolic A, Cannon K, Fonseca K, Joseph JT, et al. Subacute sclerosing panencephalitis in pregnancy. Lancet Infect Dis. 2016;16(3):366-75. Available from: https://doi.org/10.1016/s1473-3099(15)00524-1.

5. World Health Organization. Immunization, Vaccines and Biologicals-Measles WHO Available. 2018;

6. Gurnani V, Haldar P, Aggarwal MK, Das MK, Chauhan A, Murray $\mathrm{J}$, et al. Improving vaccination coverage in India: lessons from Intensified Mission Indradhanush, a crosssectoral systems strengthening strategy. BMJ. 2018;363:4782. Available from: https://dx.doi.org/10.1136/bmj.k4782.

7. Shrivastava SR, Shrivastava PS, Ramasamy J. Measles in India: challenges and recent developments. Infect Ecol Epidemiol. 2015;5:27784-27784. Available from: https://dx.doi.org/10. 3402/iee.v5.27784.

8. Risk WS. The Variable Natural History of Subacute Sclerosing Panencephalitis. Arch Neurol. 1979;36(10):610. Available from: https://dx.doi.org/10.1001/archneur.1979. 00500460044004.

9. Robertson WC, Clark DB, Markesbery WR. Review of 38 cases of subacute sclerosing panencephalitis: Effect of amantadine on the natural course of the disease. Ann Neurol. 1980;8(4):422-425. Available from: https://dx.doi.org/10. 1002/ana.410080414.

10. Anlar B, Yalaz K, Kose G, Saygi S. Beta-interferon plus inosiplex in the treatment of subacute sclerosing panencephalitis. J Child Neurol. 1998;13(11):557-566. Available from: https://doi.org/10.1177/088307389801301106.

11. Gurer YK, Kukner S, Sarica B. Intravenous gamma-globulin treatment in a patient with subacute sclerosing panencephalitis. Pediatr Neurol. 1996;14(1):72-76. Available from: https://doi. org/10.1016/0887-8994(95)00257-x.

12. Green SH, Wirtschafter JD. Ophthalmoscopic findings in subacute sclerosing panencephalitis. $\mathrm{Br} \mathrm{J}$ Ophthalmol. 1973;57(10):780-787. Available from: https://dx.doi.org/10. 1136/bjo.57.10.780.

13. Caruso JM, Robbins-Tien D, Brown W. Atypical chorioretinitis as the very first presentation of subacute sclerosing panencephalitis. Neurol. 1997;48:286-293. Available from: https: //doi.org/10.3928/0191-3913-20000301-14.

14. Park DW, Boldt HC, Messicotte SJ, Akang EE, Roos KL, Bodnar A, et al. Subacute sclerosing panencephalitis manifesting as viral retinitis: clinical and histopathologic findings. Am J Ophthal. 1997;123(4):533-575. Available from: https://doi.org/10.1016/s0002-9394(14)70179-5. 
Copyright: (C) the author(s), 2020. It is an open-access article distributed under the terms of the Creative Commons Attribution License (CC BY 4.0), which permits authors to retain ownership of the copyright for their content, and allow anyone to download, reuse, reprint, modify, distribute and/or copy the content as long as the original authors and source are cited.

How to cite this article: Kotrashetti VA, Sonawane VB, Bainade K, Nair S, Vatkar A, Kumar S. Subacute Sclerosing Panencephalitis with Subclinical Infection. Acad. Anat. Int. 2020; $6(2): 12-15$.

DOI: dx.doi.org/10.21276/aanat.2020.6.2.2

Source of Support: Nil, Conflict of Interest: None declared. 